\title{
LETTERS
}

\section{Naloxone is becoming more available in airline medical kits}

As emergency physicians with a subspecialty in aviation medicine, we agree with Dr. Rieb's response ${ }^{1}$ to an analysis article by Kodama and colleagues ${ }^{2}$ that having naloxone on board is a necessary tool to treat the increasingly common medical emergency of opioid intoxication. Some airlines (United Airlines, British Airways, Air Transat, Qantas, Frontier and Alaska Airlines) currently stock naloxone in their on-board emergency medical kits, and Air Canada is currently in the process of adding naloxone to its kits. Each airline stocks only one to two vials, which is insufficient to treat a large overdose but should be enough to reverse respiratory depression to make the diagnosis of opioid intoxication and divert the aircraft to definitive treatment.

At this time, we are not aware of any airline that offers intranasal naloxone. Although there has been a call from the Association of Flight Attendants in the
United States to be trained to administer naloxone as first responders, this is not the standard at present. Naloxone is typically stored in the emergency medical kits, which can be released only to a health care professional.

\section{Anna-Maria Carvalho MD DipAvMed}

Department of Emergency Medicine, University of British Columbia, Vancouver, BC

\section{Vincent Poirier MDCM DipAvMed}

Department of Family Medicine, McGill University, Montréal, Que.

- Cite as: CMAJ 2018 June 25;190:E775. doi: $10.1503 /$ cmaj.69467

\section{References}

1. Rieb L. Add naloxone to in-flight medical supplies [letter]. CMAJ 2018;190:E774.

2. Kodama D, Yanagawa B, Chung J, et al. "Is there a doctor on board?": Practical recommendations for managing in-flight medical emergencies. CMAJ 2018;190:E217-22.

Competing interests: Anna-Maria Carvalho and Vincent Poirier are medical consultants for Air Canada and Air Transat. 